Science, Technology and Development 34 (1): 16-26, 2015

ISSN 0254-6418 / DOI: 10.3923/std.2015.16.26

(C) 2015 Pakistan Council for Science and Technology

\title{
A Comparative Study for the Treatment of Refinery Synthetic Wastewater Containing Phenol
}

\author{
${ }^{1}$ Ibrahim Ashour, ${ }^{2}$ Hossam Altaher, ${ }^{2} \mathrm{~F}$. Sawalha and ${ }^{3}$ Munjed Maraqah \\ ${ }^{1}$ Department of Chemical Engineering, British University in Egypt, El Sherouk City, \\ Suez Desert Road, Cairo 11837, P.O. Box 43, Egypt \\ ${ }^{2}$ University of Nizwa, Department of Chemical and Petrochemical Engineering, \\ Nizwa, P.O. Box 208, PC: 133, 0096897132700, Sultanate of Oman \\ ${ }^{3}$ Department of Civil and Environmental Engineering, United Arab Emirates University, \\ P.O. Box 15551, United Arab Emirates University, United Arab Emirates
}

\begin{abstract}
In this study, removal of phenol which is classified as priority pollutant by US EPA, was experimentally investigated using different removal techniques including; adsorption using Granular Activated Carbon (GAC), biodegradation using six different active phenol uptaking bacteria, combined GAC sorption and biodegradation (Biological Activated Carbon, BAC) and GAC coupled with inactive bacteria (biosorption). A solution of $100 \mathrm{mg} \mathrm{L}^{-1}$ phenol at room temperature was considered as the wastewater. The study was performed in the temperature range $25-30^{\circ} \mathrm{C}$. The results of these different techniques revealed that activated carbon sorption is better than the other methods in removing phenol. The removal efficiency of this technique reached a value of $97 \%$ corresponding to residual phenol concentration of $3 \mathrm{mg} \mathrm{L}^{-1}$. The equilibrium sorption was reached after $48 \mathrm{~h}$ of contact. The adsorption data was better fitted to Langmuir model with adsorption capacity of $90 \mathrm{mg} \mathrm{g}^{-1}$. The adsorption was found to be second order with both intraparticle diffusion and film diffusion to control the adsorption process. The least effective removing method of phenol was the biodegradation using active bacteria alone. The residual concentration of phenol attained by this method was $17 \mathrm{mg} \mathrm{L}^{-1}$. According to the results of this study approximately $80 \%$ of the overall biological activity for removal of phenol was due to the surface sorption on the cell wall, whereas, about $20 \%$ of this activity was due to biodegradation.
\end{abstract}

$\underline{\text { Key words: Biodegradation, biological activated carbon, biosorption, phenol, wastewater }}$

\section{INTRODUCTION}

Wastewater from petroleum refineries contains a wide range of pollutants. In addition of organic pollutants such as phenol, phenol compounds and aromatic compounds which are the main reason of high Chemical Oxygen Demand (COD) of such wastewater and salinity due to the use of sea water in some stages of the process, some inorganic ions, such as $\mathrm{Mg}^{2+}, \mathrm{Ca}^{2+}, \mathrm{S}^{2-}, \mathrm{Cl}^{-}$and $\mathrm{SO}_{4}^{2-}$ are also present (Alva-Argaez et al., 2007). Phenol and phenolic compounds are widely involved in many other industries, such as dyes, plastics, cleaning agent manufacturing, pesticides in agricultural industry, construction of automobiles and appliances (Karunarathne and Amarasinghe, 2013), Steel industries (Yan et al., 2011), coal-related industries i.e., coal gasification and coking plants (Lorenc-Grabowska et al., 2013), pulp and paper (Figuerola and Erijman, 2010), polymeric resin production, petrochemical and ceramic plants (Pigatto et al., 2013). Therefore, the wastewater from these industries contains various concentrations of these compounds (Yavuz et al., 2010).
Phenol is very harmful for mammals, fish and other aquatic life organisms even at very low concentration due to its high toxicity and carcinogenic properties. Phenol is respiratory irritant and it is corrosive to skin and eyes upon direct contact (Hank et al., 2014). The overexposure to phenol affects on the central nervous system in catastrophic irreversible manner (Karunarathne and Amarasinghe, 2013). The ingestion of phenol-contaminated water may cause protein degeneration and damages of kidney, liver and pancreas in human bodies (Knop and Pilato, 1985). Phenol and other phenolic compounds can undergo chlorination, methylation or nitration reaction in wastewaters forming more harmful derivatives (Praveen and Loh, 2013). Phenol is included in the list of priority pollutants by the US Environmental Protection Agency (US EPA) and it is also classified as priority contaminants by the European Union (Lavilla et al., 2012). The toxic concentration of phenol ranges between 10 and $24 \mathrm{mg} \mathrm{L}^{-1}$ for human and between 9 and $25 \mathrm{mg} \mathrm{L}^{-1}$ for fish. Lethal blood concentration of phenol is around $150 \mathrm{mg} / 100 \mathrm{~mL}$ (Kulkarni et al., 2013). 
Phenolic compounds are the most important contaminants contributed to COD in wastewater produced from petroleum refineries (Yan et al., 2011). To meet environmental regulations for the direct discharge of water into natural waterways or municipal sewage systems, a reduction in the concentration of phenolic compounds to $<0.5 \mathrm{mg} \mathrm{L}^{-1}$ is required (Lamb et al., 2010). Many technologies have been investigated to remove phenol from water and wastewater, such as, extraction, distillation (Yan et al., 2010), ultrasonic degradation (El-Naas et al., 2010), photocatalytic degradation (Tu et al., 2013), ozonation (Zain et al., 2014), membrane separation (Busca et al., 2008), ion exchange (Karunarathne and Amarasinghe, 2013), electrochemical methods (Abdelwahab et al., 2009; Yavuz et al., 2010; Yan et al., 2011) and advanced oxidation processes (Dotto et al., 2013). Adsorption is a widely used technique for removal of many organic compounds including phenol (El-Naas et al., 2010; Zain et al., 2014). The most common adsorbents are activated carbon, carbon nanospheres, $\mathrm{SiO}_{2}$, chitin (Pigatto et al., 2013), fly ash (Chaudhary and Balomajumder, 2014) and synthetic polymeric adsorbents (Qin et al., 2013). Some low cost adsorbent such as bagasse, coconut shell, tea waste biomass and press mud were also studies (Chaudhary and Balomajumder, 2014).

Biosorption which is a technique that combines the advantages of adsorption with the use of natural, low-cost and renewable biosorbents is now investigated for removal of phenol from aqueous solutions (Dotto et al., 2013). Many biosorbents have been studied, for example, Spirulina sp. (Dotto et al., 2013), Aspergillus niger (Rao and Viraraghavan, 2002), fungal mycelia (Wu and Yu, 2006), marine seaweeds (Navarro et al., 2008), Funaliat rogii (Bayramoglu et al., 2009), chitosan (Nadavala et al., 2009) and Phanerochaete chrysosporium (Farkas et al., 2013).

Biodegradation is another method that can be used for treatment of wastewater containing phenol (Piubeli et al., 2012; Friman et al., 2013; Kalaiarasan and Palvannan, 2014; Zidkova et al., 2013). Nevertheless, the presence of phenols reduces the biodegradation of other compounds when phenol concentration exceeds $400 \mathrm{mg} \mathrm{L}^{-1}$ (Viero et al., 2008).

The purpose of this study is to evaluate the efficiency of three different techniques for removal of phenol from simulated wastewater. The selected techniques are adsorption on Granular Activated Carbon (GAC), biosorption on GAC loaded with inactive bacteria, biosorption on GAC loaded with active bacteria and biodegradation using two different microorganisms. Laboratory batch kinetics and isotherm studies were conducted to evaluate the adsorption capacity of phenol to Granular Activated Carbon (GAC). Phenol up-taking bacteria were isolated from a local enriched soil in order to study their performance in removing phenol by biodegradation and biosorption processes. The results obtained from all these different techniques were compared.

\section{MATERIALS AND METHODS}

Granular activated carbon, prepared in our lab, had a bulk density of $500 \mathrm{~g} \mathrm{~L}^{-1}$, particle size of 10-18 mesh, surface area of $900-1000 \mathrm{~m}^{2} \mathrm{~g}^{-1}$ (internal) and ash content of 5-8\% was used in this study. In this study, only single solute solutions of $100 \mathrm{mg} \mathrm{L}^{-1}$ of phenol were used to conduct the experiments. The selection was based on its load in wastewater and toxicity information (EPA., 1995).

Microorganism and growth medium: The selection of microorganism capable of degrading phenol went through several stages presented in the following sections:

Enrichment and incubation of local soil: An uncultivated soil (pesticide-free soil) was sampled near Al Jimi Campus and Al Maqam Campus of University of UAE. Samples were dried and grinded to enhance bacterial growth on solid particles. The ground soil samples were sieved to obtain sand particles of $256 \mu \mathrm{m}$. Four different concentrations of phenol (4, 200, 500 and $1000 \mathrm{mg} \mathrm{L}^{-1}$ ) were added to $150 \mathrm{~g}$ of dried soil samples to determine its toxicity levels. The batch-aerated soil media were incubated at $37^{\circ} \mathrm{C}$ for $10-15$ days.

Selective isolation of microorganisms: Direct isolation from the natural material is possible for many bacteria by using selective agar media. The first step of isolation procedure was the preparation of liquid soil broth by suspending $10 \mathrm{~g}$ of each enriched soil sample in $100 \mathrm{~mL}$ of sterile distilled water (at $121^{\circ} \mathrm{C}$ for $30 \mathrm{~min}$ ). The inoculums are subjected to serial dilution in a sterile medium until reaching end point dilution. Minimal medium that is composed of mineral salts and a carbon (energy source) only, was used as a solid media. The composition of the synthetic medium used for isolation is (in g L ${ }^{-1}$ ): $\mathrm{Na}_{2} \mathrm{HPO}_{4} 10, \mathrm{KH}_{2} \mathrm{PO}_{4} 1$, (NH)4SO 3 , $\mathrm{FeCl}_{3}$ 0.018, $\mathrm{NaCl} 0.2, \mathrm{MgSO}_{4} .7 \mathrm{H}_{2} \mathrm{O} 0.2, \mathrm{CaCl}_{2}$ 0.08, Yeast Extract 0.5) (Pai et al., 1995). The compound used to solidify media in Petri dishes was nutrient free agar (20 $\mathrm{g} \mathrm{L}^{-1}$ mineral liquid). Phenol was added with different concentrations (200, 500, $\mathrm{mg} \mathrm{L}^{-1}$ and 1, $5 \mathrm{~g} \mathrm{~L}^{-1}$ ), one for each thio broth previously prepared.

Identification of bacterial isolates to species level: Gram-negative and -positive bacterial isolates were identified using standard methods including Gram stain and general morphology, spore formation, colony morphology, pigmentation, physiological and biochemical 
Table 1: Identification results of the isolated bacteria

\begin{tabular}{ll}
\hline Source of energy and isolate numbers & Identification \\
\hline Phenol & Bacillus firmus \\
P2 & Bacillus longisporus \\
P6 & Pseudomonas fluorescens \\
P7 & Bacillus pumilus \\
P8 & Pseudomonas putida \\
P10 & Pseudomonas spp. \\
P11 & \\
\hline
\end{tabular}

tests as described by Palleroni (1984) and Sneath (1986), respectively. The API 20E diagnostic strips (bioMerieuxsa, Marcy l'Etoile, France) and the API 20B (API System SA, La Balme Les Grottes, Montalieu, Vercieu, France) were also used in the identification. These isolates were identified as presented in Table 1, where $\mathrm{P}$ is phenol-utilizing bacteria. All identifications were carried out in the Department of Biology, United Arab Emirates University.

Analytical techniques and instruments: The concentration of residual phenol in the adsorption, degradation and biosorption systems were measured using 160-A double beam UV spectroscopy (Shimadzu)at wavelength $(\lambda=270 \mathrm{~nm})$. Membrane syringe filters with pore size $=0.45 \mu \mathrm{m}$ were used to remove solid particles, whereas, pore size of $0.2 \mu \mathrm{m}$ was used to sterilize the filtrate liquid from any possible contamination of biomass during the degradation and the biosorption experiments. Moreover, bacterial growth was measured at $\lambda=600 \mathrm{~nm}$ as Transmittance percentage (T\%).

Batch studies: Wastewater contaminated with phenol in the range of 5-500 $\mathrm{mg} \mathrm{L}^{-1}$ can be treated by biological process (Monteiro et al., 2000). Moreover, the highest growth rate of biomass due to the degradation of phenol was observed at an initial concentration of approximately $100 \mathrm{mg} \mathrm{L}^{-1}$. For adsorption experiments, $50 \mathrm{mg}$ of GAC was added to $20 \mathrm{~mL}$ of $100 \mathrm{mg} \mathrm{L}^{-1}$ phenol solution in $120 \mathrm{~mL}$ septum bottles in order to conduct the adsorption rate experiments. For degradation and biosorption experiments, $0.5 \mathrm{~g}$ of GAC was added to $200 \mathrm{~mL}$ of mineral basal medium of $100 \mathrm{mg} \mathrm{L}^{-1}$ phenol in $1 \mathrm{~L}$ Erlenmeyer flasks ( $50 \mathrm{mg} / 20 \mathrm{~mL}$ ) with isolated bacteria. Two equal volumes of $100 \mathrm{~mL}$ cultivated bacteria were added to 2 Erlenmeyer flasks in order to start degrading or biosorping with the same concentration of bacteria. All batch systems were aerated by shaking the flasks and bottles to keep the oxygen concentration constant and not limiting for the degrading bacteria (Monteiro et al., 2000). The shaking rate was kept constant at $120 \mathrm{rpm}$. The experiments were conducted at the initial $\mathrm{pH}$ of the systems which is 5.65 . This value is close to the $\mathrm{pH}$ value at which highest degradation levels were obtained (Annadurai et al., 2002). The temperature of the system was fixed by a water bath shaker at $25^{\circ} \mathrm{C}$. The range of temperature between $25-30^{\circ} \mathrm{C}$ provided the highest growth rate of $P$. putida (Monteiro et al., 2000; Annadurai et al., 2002).

Effect of time on adsorption of phenol on GAC: The preliminary kinetic experiment was an essential step to show the time required to reach equilibrium for phenol. Twenty screw cap vials were used in this experiment. Each sample was prepared in $120 \mathrm{~mL}$ vials with $50 \mathrm{mg}$ of GAC with phenol solution leaving $100 \mathrm{ml}$ headspace. The bottles were placed on a water bath shaker at $120 \mathrm{rpm}$ and $25^{\circ} \mathrm{C}$. Periodically, one vial was removed from the water bath at a certain time. Then, the filtrate was analyzed using UV spectroscopy to determine the residual of phenol concentration. The control sample (blank solution with no activated carbon) was checked periodically to determine the loss of phenol due to volatilization and/or adsorption on the container walls.

Adsorption equilibrium of phenol on GAC: The adsorption isotherm was conducted by adding different masses of GAC $(5,10,20,30,40,50,60$ and $70 \mathrm{mg})$ to $20 \mathrm{~mL}$ of $100 \mathrm{mg} \mathrm{L}^{-1}$ phenol solution in $120 \mathrm{~mL}$ glass screw cap vials. Each weight was duplicated in order to analyze the residual concentration of phenol with the same amount of GAC after 24 and $48 \mathrm{~h}$.

Biodegradation experiments: The main objective of these experiments is to examine the potential of phenol removal from the synthetic wastewater by one or more type of microorganism. One liter of mineral media was prepared. Pre-weighed phenol $(0.25 \mathrm{~g})$ was added to mineral media. Under laminar air-flow cabinet, a single microorganism suspension of $100 \mathrm{~mL}$ was contacted with $100 \mathrm{~mL}$ mineral solution of $200 \mathrm{mg} \mathrm{L}^{-1}$ phenol concentration in order to reach $100 \mathrm{mg} \mathrm{L}^{-1}$ as a final phenol concentration. The openings of all Erlenmeyer flasks were flamed and the graduated cylinders were sterilized by $10 \%$ methanol solution (Sigma Aldrich) in order to prevent air contamination. Then, the $200 \mathrm{~mL}$ of the final solution was poured in 1-L Erlenmeyer flask and closed by a thick layer of cotton. The preparation procedure of $200 \mathrm{~mL}$ mineral solution containing P7 microorganism suspension was repeated to prepare the other five solutions. The six Erlenmeyer flasks were placed on a water bath shaker set for 2 weeks. The results obtained from the degradation experiment were used to determine the uptake rate differences between the six single strains of microorganisms capable to biodegrade phenol. The reduction of phenol concentration was measured, respectively by filtering a sample of each solution through $0.2 \mu \mathrm{m}$ syringe filter and analyzing the filtrate by 160-A Double Beam UV spectroscopy (Shimadzu). Each filtrate sample was placed in a quartz 
cell and the blank sample was placed in the other cell with zero absorbance value. The microbial growth rate of single strain was measured directly by UV spectroscopy without filtration and the control sample was a sterile mineral media. Ten percent ethanol solution was used to sterilize all equipment and apparatus needed for analysis.

Biological Activated Carbon experiments (BAC): The procedure used in biological activated carbon experiments was similar to the one used during the degradation experiments. The only difference, was the addition of $500 \mathrm{mg}$ of GAC to $200 \mathrm{~mL}$ of mineral media contained $100 \mathrm{mg} \mathrm{L}^{-1}$ phenol and $100 \mathrm{~mL}$ of single microorganism suspension. Then, one strain was selected to study the biosorption efficiency with dead biomass and compare it with the results obtained from the biodegradation using live bacteria. Pseudomonas fluorescens individual microorganism suspension of $100 \mathrm{~mL}$ that had the same microbial turbidity percentage of the previous degradation tests were inactivated by autoclave $\left(121^{\circ} \mathrm{C}, 30 \mathrm{~min}\right)$. These two steps were repeated to prepare 200 final solutions containing the initial concentrations of the organic chemicals, the specific amount of sorbent and $40 \%$ of the microbial turbidity percentage of $\mathrm{P} 7$ for about $72 \mathrm{~h}$.

Combination of GAC and inactive bacteria (Biosorption): Two strains were selected to study the biosorption efficiency with dead biomass and compare teem with the results obtained from using live bacteria. Earlier studies on the biosorption of toxic organics with fungal biomass have indicated that better removal was obtained with dead fungal biomass than with live biomass (Rao and Viraraghavan, 2002). Pseudomonas fluorescens individual microorganism suspension of $100 \mathrm{~mL}$ that had the same microbial turbidity percentage of the degradation experiments was inactivated by autoclave $\left(121^{\circ} \mathrm{C}, 30 \mathrm{~min}\right)$. Then, $100 \mathrm{~mL}$ of the dead suspension of P7 was combined with $100 \mathrm{~mL}$ of mineral solution with $100 \mathrm{~mL}$ phenol concentration and $500 \mathrm{mg}$ GAC in $1 \mathrm{~L}$ flask. These two steps were repeated to prepare $200 \mathrm{~mL}$ final solutions contained the initial concentrations of phenol, the specific amount of sorbent and $40 \%$ of the microbial turbidity percentage of P7. In this case, the adsorption capacities of different densities of dead microorganism combined with GAC were examined and determined at $25^{\circ} \mathrm{C}$ and $120 \mathrm{rpm}$ of the water bath shaker for about $72 \mathrm{~h}$.

\section{RESULTS AND DISCUSSION}

\section{GAC adsorption}

Equilibrium study: The equilibrium studies are very important in understanding the adsorption mechanism, designing the adsorption process, identifying the surface properties of the sorbent and the affinities between the adsorbent and adsorbate molecules (Pacurariu et al., 2013). Analysis of the adsorption equilibrium data was done using Langmuir, Freundlich, Temkin and Dubini-Radushkevich models. The Langmuir adsorption model is based on the assumption that adsorption takes place on specific sites on the surface of adsorbent. No lateral interaction takes place between the sorbed molecules. The maximum adsorption corresponds to a saturated monolayer of solute molecules on the adsorbent surface.

The linearized form of this model is given by the following equation (Foo and Hameed, 2010):

$$
\mathrm{C}_{\mathrm{e}} / \mathrm{q}_{\mathrm{e}}=1 /\left(\mathrm{q}_{\mathrm{m}} \mathrm{k}_{\mathrm{L}}\right)+\mathrm{C}_{\mathrm{e}} / \mathrm{q}_{\mathrm{m}}
$$

where, $\mathrm{C}_{\mathrm{e}}\left(\mathrm{mg} \mathrm{L}^{-1}\right)$ is the equilibrium concentration, $\mathrm{q}_{\mathrm{e}}\left(\mathrm{mg} \mathrm{g}^{-1}\right)$ is the adsorption capacity at equilibrium, $\mathrm{q}_{\mathrm{m}}\left(\mathrm{mg} \mathrm{g}^{-1}\right)$ is the maximum adsorption capacity and $\mathrm{K}_{\mathrm{L}}\left(\mathrm{L} \mathrm{mg} \mathrm{mg}^{-1}\right)$ is constant related to adsorption rate. The favorability of the adsorption is given by the dimensionless separation factor $\mathrm{R}_{\mathrm{L}}$ which is given by Eq. 2:

$$
\mathrm{R}_{\mathrm{L}}=1 /\left(1+\mathrm{k}_{\mathrm{L}} \mathrm{C}_{\mathrm{o}}\right)
$$

where, $\mathrm{C}_{\mathrm{o}}\left(\mathrm{mg} \mathrm{L}^{-1}\right)$ is the initial dye concentration and $\mathrm{K}_{\mathrm{L}}$ is Langmuir constant. The value of separation factor indicates the favorability of the adsorption process as follows:

Unfavorable $\left(\mathrm{R}_{\mathrm{L}}>1\right)$, linear $\left(\mathrm{R}_{\mathrm{L}}=1\right)$, favorable $\left(0<R_{L}<1\right)$ and irreversible $\left(R_{L}=0\right)$

On the other hand, Freundlich isotherm is an empirical equation employed to describe adsorption on heterogeneous surfaces (De Martino et al., 2013). The linear form of this model is represented by (Foo and Hameed, 2010):

$$
\ln \mathrm{q}_{\mathrm{e}}=\ln \mathrm{k}_{\mathrm{f}}+1 / \mathrm{n}\left(\ln \mathrm{C}_{\mathrm{e}}\right)
$$

where $\mathrm{q}_{\mathrm{e}}$ and $\mathrm{C}_{\mathrm{e}}$ have the same designation as Langmuir equation, $\mathrm{k}_{\mathrm{f}}\left(\mathrm{mg} \mathrm{g}^{-1}(1 \mathrm{mg}) 1 / \mathrm{n}\right)$ is a constant related to the bonding energy and $1 / \mathrm{n}$ is identifying the adsorption intensity of adsorbate onto adsorbent. If the value of exponent $\mathrm{n}$ is greater than 1 , then the adsorption represents favorable adsorption conditions.

Temkin isotherm (Foo and Hameed, 2010) assumes that the decrease in the heat of adsorption is linear rather than logarithmic, as implied in Freundlich isotherm. The adsorption process is characterized by a uniform distribution of binding energies all over the surface of 
Sci. Technol. Dev., 34 (1): 16-26, 2015

Table 2: Adsorption parameters for the applied adsorption models

\begin{tabular}{|c|c|c|c|c|c|c|c|c|c|c|c|c|c|}
\hline \multirow[b]{2}{*}{ Equilibrium times } & \multicolumn{3}{|c|}{ Freundlich } & \multicolumn{4}{|c|}{ Langmuir } & \multicolumn{3}{|c|}{ Temkin } & \multicolumn{3}{|l|}{$\mathrm{D}-\mathrm{R}$} \\
\hline & $\mathrm{R}^{2}$ & $\mathrm{~K}_{\mathrm{f}}$ & $\mathrm{n}$ & $\mathrm{R}^{2}$ & $\mathrm{q}_{\mathrm{m}}$ & $\mathrm{K}_{\mathrm{L}}$ & $\mathrm{R}_{\mathrm{L}}$ & $\mathrm{R}^{2}$ & $\mathrm{~B}_{\mathrm{T}}$ & $\mathrm{K}_{\mathrm{T}}$ & $\mathrm{R}^{2}$ & $\mathrm{q}_{\mathrm{m}}$ & E \\
\hline$\overline{24 \mathrm{~h}}$ & 0.964 & 23.714 & 3.300 & 0.984 & 90.9 & 0.250 & 0.039 & 0.964 & 0.324 & 17257 & 0.885 & 57.970 & 0.745 \\
\hline $48 \mathrm{~h}$ & 0.965 & 27.606 & 3.086 & 0.990 & 90.9 & 0.167 & 0.057 & 0.965 & 0.303 & 33928 & 0.887 & 45.787 & 1.581 \\
\hline
\end{tabular}

adsorbent. One very important feature of this model is the presence of a factor that explicitly takes into account the interaction between the adsorbate and the adsorbent. The linear form is given by:

$$
\begin{gathered}
\mathrm{q}_{\mathrm{e}}=\mathrm{B}_{\mathrm{T}}\left(\ln \mathrm{k}_{\mathrm{T}}\right)+\mathrm{B}_{\mathrm{T}} \ln \left(\mathrm{C}_{\mathrm{e}}\right) \\
\mathrm{B}_{\mathrm{T}}=(\mathrm{RT}) / \mathrm{b}
\end{gathered}
$$

where, $\mathrm{q}_{\mathrm{e}}\left(\mathrm{mg} \mathrm{g}^{-1}\right)$ and Ce $\left(\mathrm{mg} \mathrm{L}^{-1}\right)$ are the same as in Langmuir equation, $\mathrm{R}$ is the universal gas constant (8.314 $\left.\mathrm{J} \mathrm{M}^{-1} \mathrm{~K}\right)$, b $\left(\mathrm{J} \mathrm{M}^{-1}\right.$ ) is Temkin isotherm constant related to the heat of adsorption and $\mathrm{T}$ is the absolute temperature $(\mathrm{K})$. The constant $\mathrm{K}_{\mathrm{T}}\left(\mathrm{L} \mathrm{mg}^{-1}\right)$ is the equilibrium binding constant, corresponding to maximum binding energy. The Dubinin-Radushkevich linearized equation is given by the following equation (Foo and Hameed, 2010):

$$
\ln q_{\mathrm{e}}=\ln \mathrm{q}_{\mathrm{m}}-\mathrm{B} \varepsilon^{2}
$$

where, $\mathrm{q}_{\mathrm{e}}$ is the same as in Langmuir model, $\mathrm{q}_{\mathrm{m}}$ represents the maximum adsorption capacity of adsorbent $\left(\mathrm{mg} \mathrm{g}^{-1}\right)$ and $\mathrm{B}$ is constant related to the mean free energy of adsorption per mole of adsorbate.

The Polanyi potential is given by:

$$
\begin{gathered}
\varepsilon=R T \ln \left(1+1 / C_{e}\right) \\
E=1 /(2 B)^{0.5}
\end{gathered}
$$

This model is helpful in determining the nature of the adsorption process; physical or chemical. It can also be used for estimating the maximum adsorption capacity of the system.

Table 2 summarizes the fitting of the experimental data to the four models. The fitting of the data to the models was compared using the correlation coefficient $\left(\mathrm{R}^{2}\right)$. It is clear from the data that Langmuir best fits the data which suggests the adsorption to take place on a monolayer on the surface of GAC. The separation factor $R_{L}$ is much less than 1 which implies low surface energy. High affinity and stronger bonding of the adsorbents to the adsorbate molecules. The maximum adsorption capacities at the two periods studied ( 24 and $48 \mathrm{~h}$ ) are the same (90.9 $\mathrm{mg} \mathrm{g}^{-1}$ ) indicating that equilibrium has been attained within $24 \mathrm{~h}$. This value is comparable to the experimental value which assures the good fitting of the data to this model. Many researchers reported the fitting of phenol adsorption to Langmuir model (Dabrowski et al., 2005; Derylo-Marczewska et al., 2006; Qian et al., 2009).

Meanwhile, Freundlich fits to the data is good with $\mathrm{R}^{2}=0.965$. The value of $\mathrm{n}$ being greater than 1 assures the high affinity of the adsorbent to the adsorbate. Additionally, as the $\mathrm{K}_{\mathrm{f}}$ value increases, as illustrated in Table 2 by the values 23.714 and 27.606 (mg g $\left.{ }^{-1}(\mathrm{mg}) 1 / \mathrm{n}\right)$ at 24 and $48 \mathrm{~h}$, respectively, the adsorption capacity of the adsorbent increases.

Temkin isotherm was studied to explore the Gibbs free energy change $(\Delta \mathrm{Go})$ as:

$$
\mathrm{B}_{\mathrm{t}}=\mathrm{RT} / \Delta \mathrm{Go}
$$

The values of $\Delta \mathrm{Go}$ was found to be 7.65 and $8.18 \mathrm{~kJ} \mathrm{M}^{-1}$ for the two equilibrium time periods studied, 24 and $48 \mathrm{~h}$, respectively. These values were lower than $10 \mathrm{~kJ} \mathrm{M}^{-1}$ indicating a physical adsorption process (Kumar and Kirthika, 2009).

The approach was usually applied to distinguish the physical and chemical adsorption of metal ions. If the mean free energy, $\mathrm{E}$, is less than $8 \mathrm{~kJ} \mathrm{M}^{-1}$, the adsorption is physical in nature. If the value is between 8 and $16 \mathrm{~kJ} \mathrm{M}^{-1}$, ion exchange may take place. If the value is greater than $16 \mathrm{~kJ} \mathrm{M}^{-1}$, the adsorption process has a chemical nature. It can be noticed that although the correlation coefficient values for adsorption periods are low, the E-values are less than 8, indicating that the adsorption process has a physical nature. This agrees well with the results obtained from Temkin model.

Kinetic study: Adsorption kinetic is important property since it describes the rate of adsorption which in turn helps estimating the time required for adsorption in the reactor. It determines the mechanism of the adsorption process which helps in controlling the adsorption reaction. It also helps in defining the efficiency of sorption. The experimental data on the effects of the contact time on the adsorption capacity for $100 \mathrm{mg} \mathrm{L}^{-1}$ phenol are shown in Fig. 1.

It can be observed that the phenol uptake is very fast in the first $4.5 \mathrm{~h}$. The $82 \%$ of the removal efficiency was attained within this period. A control sample was used and it showed no loss of phenol due to volatilization and/or adsorption on the container walls under the conditions of the experiments. The adsorption process 




Fig. 1: Effect of time on adsorption of phenol on GAC

Table 3: Adsorption rate models of phenol on GAC

\begin{tabular}{lr}
\hline Parameters & Values \\
\hline Pseudo first order & \\
$\mathrm{R}^{2}$ & 0.877 \\
$\mathrm{~K}_{1}$ & 0.270 \\
$\mathrm{q}_{\mathrm{m}}$ & 33.650 \\
Pseudo second order & \\
$\mathrm{R}^{2}$ & 0.977 \\
$\mathrm{~K}_{2}$ & 0.018 \\
$\mathrm{q}_{\mathrm{m}}$ & 38.460 \\
\hline
\end{tabular}

became slower near the equilibrium that was reached after $21 \mathrm{~h}$. This can be attributed to the large number of vacant surface sites available for adsorption at the initial stage. In time, these sites got occupied and the remaining adsorbate ions would for the remaining sites. Also, a repulsive force between the already adsorbed molecules and the molecules remained in the liquid phase will arise. This repulsive force will resist the adsorption process. These results are in agreement with the literature data (Al-Muhtaseb et al., 2011; Ozdes et al., 2011; Huang et al., 2012). Another reason for this variation of adsorption rate is the concentration gradient. At the early stage of adsorption the concentration gradient is high which accelerate the adsorption process. In time, the concentration gradient decreases causing decrease in the adsorption rate.

To estimate the rate of adsorption of phenol on GAC, pseudo first order, pseudo second order models were applied. The experimental data was fitted to Elovich, Intraparticle and Boyd diffusion models to investigate the mechanism of adsorption (reference). The pseudo first order rate equation of Lagergren, is expressed by the following equation:

$$
\ln \left(\mathrm{q}_{\mathrm{e}}-\mathrm{q}_{\mathrm{t}}\right)=\ln \mathrm{q}_{\mathrm{e}}-\mathrm{k}_{1} \mathrm{t}
$$

where, $k_{1}\left(h^{-1}\right)$ is the rate constant of the first order adsorption rate, $\mathrm{q}_{\mathrm{e}}$ and $\mathrm{q}_{\mathrm{t}}\left(\mathrm{mg} \mathrm{g}^{-1}\right)$ are the concentration of phenol in solution at equilibrium and at any time $\mathrm{t}(\mathrm{h})$, respectively. The linearized form of pseudo second order equation is given by the following equation:

$$
\mathrm{t} / \mathrm{q}_{\mathrm{t}}=1 / \mathrm{k}_{2} \mathrm{q}_{\mathrm{m} 2}+\mathrm{t} / \mathrm{qm}
$$

where, $\mathrm{k}_{2}\left(\mathrm{~g} \mathrm{mg}^{-1} \mathrm{~h}^{-1}\right)$ is the rate constant of the pseudo second order equation, $\mathrm{q}_{\mathrm{m}}\left(\mathrm{mg} \mathrm{g}^{-1}\right)$ is the maximum adsorption capacity, $\mathrm{q}_{\mathrm{t}}\left(\mathrm{mg} \mathrm{g}^{-1}\right)$ is the amount adsorbed at time $t(h)$. While the pseudo first order model only describes the initial state of adsorption, the pseudo second order model predicts the behavior over the entire range of adsorption process including external liquid film diffusion, surface adsorption and intraparticle diffusion.

It has been reported that the adsorption of phenols usually fits the pseudo-second order kinetic model (Mohanty et al., 2006; Qian et al., 2009). Present results (Table 3) confirm this finding. The correlation coefficient $\left(\mathrm{R}^{2}\right)$ of the second order fitting $(0.977)$ is much higher than that of first order (0.788). Furthermore, the experimental qe value for second order agrees with calculated value better than of first order. The fitting of the data to the second order model suggests that the rate of adsorption is affected by the concentration of both the adsorbent and adsorbate molecules in the system (Abramian and El-Rassy, 2009).

The adsorption process takes place through four stages. First the adsorbate moves from the bulk of the solution towards the thin layer adjacent to the surface of adsorbent. Second, the adsorbate molecules diffuse through the thin layer to surface of adsorbent. Third, the adsorbate molecules diffuse through the pore (intraparticle diffusion). Fourth, the molecules are adsorbed on the surface of adsorbed or attached to the functional groups on the surface of adsorbent. The first and last stages are usually fast and do not control the adsorption process. So, the rate limiting step is either the diffusion through the liquid layer or the diffusion through the pores (Moussavi and Khosravi, 2011). If the former is the rate limiting step the experimental data when fitted to the intraparticle diffusion model $\left(\mathrm{q}_{\mathrm{t}} \mathrm{vs} \mathrm{t}^{0.5}\right)$ will give straight line passing though the origin. If the line does not pass by the origin, then intraparticle diffusion model is not the only rate limiting mechanism. Diffusion through the pores may participate in controlling the adsorption process.

The linearized form of Intraparticle diffusion model is given by the following equation:

$$
\mathrm{q}_{\mathrm{t}}=\mathrm{k}_{\mathrm{id}} \mathrm{t}^{0.5}+\mathrm{C}
$$

where, $\mathrm{q}_{\mathrm{t}}\left(\mathrm{mg} \mathrm{g}^{-1}\right)$ is the amount adsorbed at time $\mathrm{t}(\mathrm{h})$ and kid (mg g ${ }^{-1} h^{0.5}$ ) is the rate constant for the intraparticle diffusion model. 
Sci. Technol. Dev., 34 (1): 16-26, 2015



Fig. 2: Fitting the experimental data of adsorption of phenol on GAC to intraparticle diffusion model

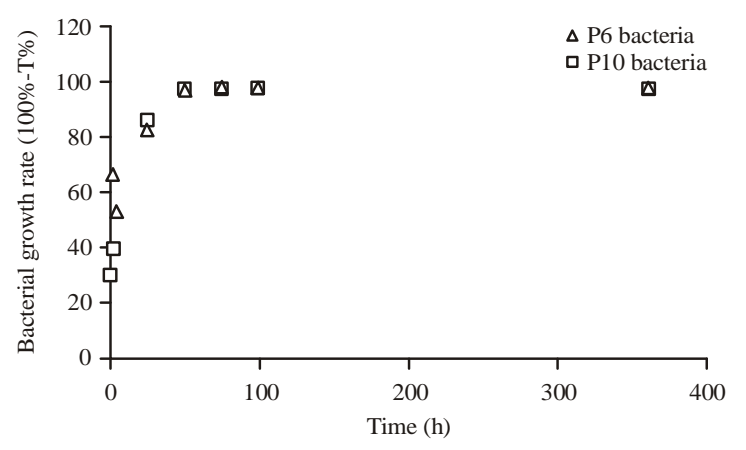

Fig. 3: Growth cycles of two phenol-utilizing bacteria $\left(\mathrm{C}_{\text {o phenol }}=100 \mathrm{mg} \mathrm{L}^{-1}\right)$

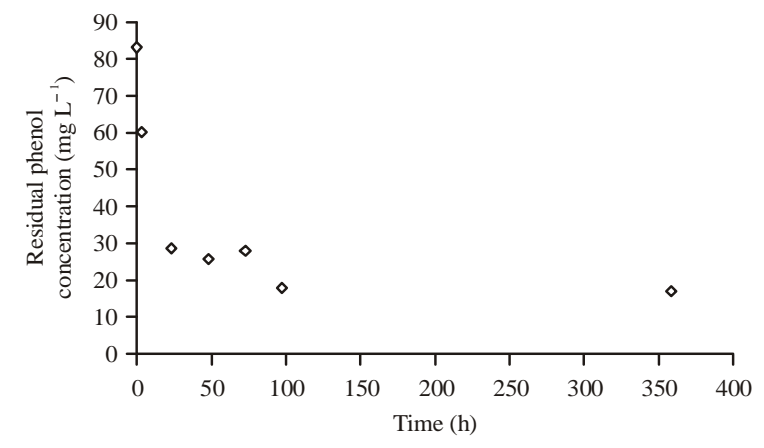

Fig. 4: Uptake of phenol by active P10 species (100 vol \% bacterial suspension)

Table 4: Kinetic diffusion parameters for the adsorption of phenol on

\begin{tabular}{|c|c|c|c|c|}
\hline \multirow[b]{2}{*}{ Equilibrium times } & \multicolumn{3}{|c|}{ Intraparticle diffusion model } & \multirow{2}{*}{$\begin{array}{l}\text { Film } \\
\text { diffusion mode } \\
\mathrm{R}^{2}\end{array}$} \\
\hline & $\mathrm{R}^{2}$ & $\mathrm{~K}_{\mathrm{id}}$ & $\mathrm{C}$ & \\
\hline At the beginning & 0.97 & 15.500 & 2.301 & 0.986 \\
\hline Near equilibrium & 0.817 & 0.283 & 35.09 & 0.936 \\
\hline
\end{tabular}

The film diffusion model (Boyd model) is expressed as:

$$
B_{t}=-0.4977-\ln (1-F)
$$

where, $B_{t}$ is the mathematical function of $F$ and $F$ represents the fraction of solute adsorbed at time $\mathrm{t}(\mathrm{h})$ and:

$$
\mathrm{F}=\mathrm{q}_{\mathrm{l}} / \mathrm{q}_{\mathrm{e}}
$$

According to the model, if the plot $\mathrm{B}_{\mathrm{t}}$ versus t passes through the origin, pore diffusion is the rate limiting step. Otherwise, the adsorption process is intraparticle diffusion controlled.

Figure 2 and Table 3 depict the fitting of the experimental data to intraparticle diffusion model. It is clear the data is represented by two different parts. The first part which is a fast one represents the early adsorption of phenol. It takes place before approximately $4.5 \mathrm{~h}$ and the equilibrium adsorption zone after approximately $6 \mathrm{~h}$.

As stated before, the concentration gradient of the phenol at the early stage of adsorption provided a sufficiently strong adsorption force to overcome the external resistance completely. This condition resulted in a high film diffusion rate. Therefore, the rate-controlling step was the intraparticle diffusion. The concentration gradient of phenol significantly decreased with time which resulted in a significant reduction in the adsorption force. Therefore, the diffusion rate was reduced and the rate limiting step was film diffusion.

Biodegradation experiments: Six species of microorganisms are responsible for phenol degradation. Both P6 and P10 were selected as a representative species to describe the uptake of phenol. All experiments were conducted using $200 \mathrm{~mL}$ solutions of initial phenol concentration of $100 \mathrm{mg} \mathrm{L}^{-1}$ at a shaking rate of $120 \mathrm{rpm}$. Figure 3 shows the bacterial growth for P10 and P6 for 350 h experiments. No lag phase of growth was observed for P10 strain. This observation may be due to the selective isolation of bacteria on phenol. This preparation was allowed the cultures to acclimate to the initially high concentrations of phenol ranged between 200-500 mg L $\mathrm{L}^{-1}$.

Figure 4 shows the phenol concentration in solution as function of time. As can be seen from the figure, about $65 \%$ of the phenol was removed in the first $24 \mathrm{~h}$ and the experiment reached equilibrium after $100 \mathrm{~h}$.

The maximum phenol uptake is about $80 \%$ of the initial concentration. The reduction of phenol during the process is due to the biological action of bacteria (degradation) and biosorption of its wall cells only. The portion of biological mechanisms used for metabolic purposes was observed and confirmed by the increase in bacterial growth due to the uptake of the organic phenol. Part of this uptake was used to generate new cells and the other part for the natural metabolizing processes inside the bacteria. 
Sci. Technol. Dev., 34 (1): 16-26, 2015



Fig. 5: Phenol concentration and bacterial growth in bacterial system and BAC system using P10 strain

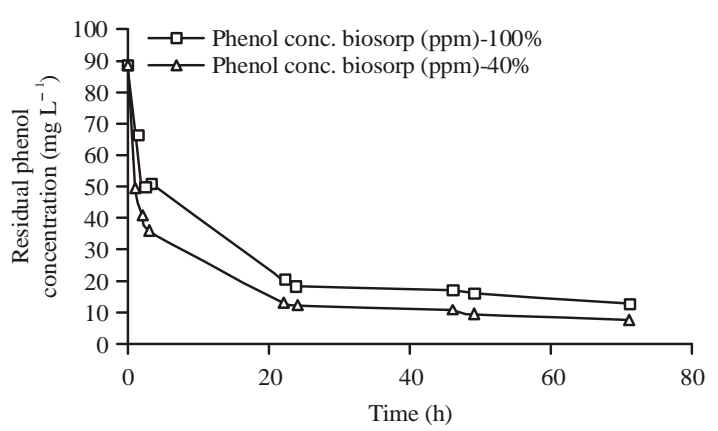

Fig. 6: Removal of phenol using inactive P7 biomass of two different concentrations (40 and $100 \mathrm{vol} \%$ inactive bacterial suspension)

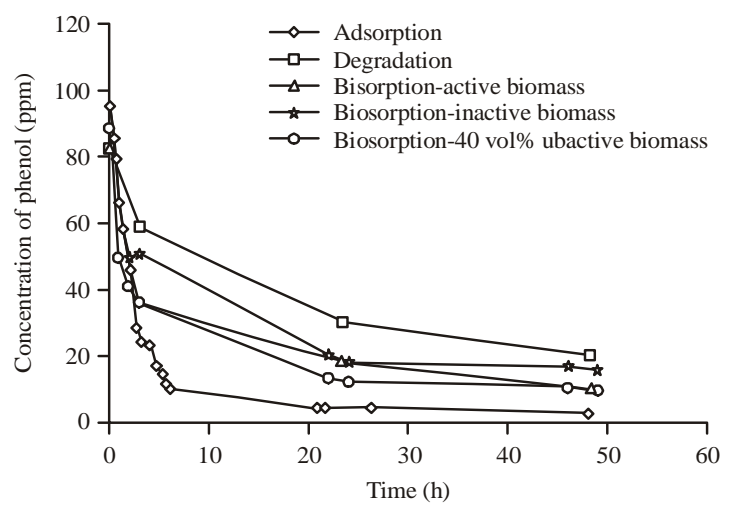

Fig. 7: Removal of phenol compared for the different methods: GAC adsorption, removal using P7 bacteria, GAC+active P7, GAC+inactive P7 and GAC +40 vol \% inactive P7 (Cophenol $=100 \mathrm{mg}$ $\mathrm{L}^{-1} ; \mathrm{T}=25^{\circ} \mathrm{C}$, rshaking $\left.=120 \mathrm{rpm}\right)$

Biological activated carbon: Active P10 was combined with $500 \mathrm{mg}$ GAC per $200 \mathrm{~mL}$ for the sorption of $100 \mathrm{mg} \mathrm{L}^{-1}$ phenol solution. The growth rate of P10 was 3.3 times its initial value during the biological process (using biomass only). This value reduced to 2.9 times for the BAC system. Figure 5 shows the P10 bacterial growth as function of time for both BAC and biomass alone. In addition, the figure shows the reduction of phenol in the solution as function of time for both BAC and biomass systems. As can be depicted by the figure, there is $12 \%$ enhancement in the removal of phenol when using biomass combined with GAC compared to the biomass system alone. This phenomenon was observed for all 6 species of phenol up-taking bacteria. On the other hand, the blockage of the GAC by the bacterial cells had reduced its adsorption efficiency.

GAC with inactive bacteria (biosorption): Inactive bacteria were considered as adsorbing material whose cell walls contained the active sites necessary for the adsorption of the phenol. Sorption using inactive biomass was carried out for $72 \mathrm{~h}$. It was interesting to observe that removal of phenol using inactive bacteria had given results similar to those obtained by active bacteria. The main conclusion was that the portion of phenol used for bacterial metabolism and for the production of new cells was very low compared to the amounts adsorbed by the cell walls of the bacteria. Therefore, the mechanism of biosorption using biomass combined with GAC was based on the adsorption capacity of bacteria by the active sites available for these species of microorganisms.

Figure 6 shows phenol removal using GAC coupled with $100 \mathrm{vol} \%$ inactive biomass and $40 \mathrm{vol} \%$ inactive biomass. As can be seen from the figure, the use of $40 \mathrm{vol} \%$ inactive biomass had enhanced the biosorption of phenol compared to $100 \mathrm{vol} \%$ inactive biomass concentration. This can be explained as; reducing the concentration of bacteria used for biosorption would reduce the percentage of GAC sites blocked by bacteria and thus better phenol removal. Figure 7 gives the concentration of phenol removed by different techniques.

\section{CONCLUSION}

Sorption of phenol on activated carbon is characterized by a fast initial rate followed by a very slow sorption rate and equilibrium sorption was achieved within $48 \mathrm{~h}$. Less removal (compared to removal by activated carbon) of phenol was obtained when biomass alone was used. The removal was enhanced using a combined system of biomass and activated carbon but did not reach the removal obtained by activated carbon alone. 
This indicated that use of biomass in suspension blocks some of the available area for sorption on the activated carbon. Biodegradation did not play a major role in the removal of phenol. The contribution of biodegradation process in the overall removal of phenol was about $20 \%$ of the total biological activity of bacteria. Reducing the bacterial concentration in the BAC system reduces the adverse effect of blocking the active sites on GAC. Furthermore, the use of immobilized cells attached on solid material instead of using suspended cells or the use of systems in series instead of combined ones may be a good suggestion to have better removal efficiency where the phenol is adsorbed on the GAC then free extra phenol in solution can be adsorbed on the bacteria cell walls.

\section{REFERENCES}

Abdelwahab, O., N.K. Amin and E.Z. El-Ashtoukhy, 2009. Electrochemical removal of phenol from oil refinery wastewater. J. Hazardous Mat., 163: 711-711.

Abramian, L. and H. El-Rassy, 2009. Adsorption kinetics and thermodynamics of azo-dye Orange II onto highly porous titania aerogel. Chem. Eng. J., 150: 403-410.

Al-Muhtaseb, A.H., K.A. Ibrahim, A.B. Albadarin, O. Ali-khashman, G.M. Walkerb and M.N.M. Ahmad, 2011. Remediation of phenol-contaminated water by adsorption using poly (methyl methacrylate) (PMMA). Chem. Eng. J., 168: 691-699.

Alva-Argaez, A., A.C. Kokossis and R. Smith, 2007. The design of water-using systems in petroleum refining using a water-pinch decomposition. Chem. Eng. J., 128: 33-46.

Annadurai, G., R.S. Juang and D.J. Lee, 2002. Microbiological degradation of phenol using mixed liquors of Pseudomonas putida and activated sludge. Waste Manage., 22: 703-710.

Bayramoglu, G., I. Gursel, Y. Tunali and M.Y. Arica, 2009. Biosorption of phenol and 2-chlorophenol by Funaliatrogii pellets. Bioresour. Technol., 100: 2685-2691.

Busca, G., S. Berardinelli, C. Resini and L. Arrighi, 2008. Technologies for the removal of phenol from fluid streams: A short review of recent developments. J. Hazard. Mater., 160: 265-288.

Chaudhary, N. and C. Balomajumder, 2014. Optimization study of adsorption parameters for removal of phenol on aluminum impregnated fly ash using response surface methodology. J. Taiwan Instit. Chem. Eng., 45: 852-859.
Dabrowski, A., P. Podkoscielny, Z. Hubicki and M. Barczak, 2005. Adsorption of phenolic compounds by activated carbon-a critical review. Chemosphere, 58: 1049-1070.

De Martino, A., M. Iorio, P.D. Prenzler, D. Ryan, H.K. Obied and M. Arienzo, 2013. Adsorption of phenols from olive oil waste waters on layered double hydroxide, hydroxyaluminium-iron-coprecipitate and hydroxyaluminium-ironmontmorillonite complex. Applied Clay Sci., 80: 154-161.

Derylo-Marczewska, A., A. Swiatkowski, B. Buczek and S. Biniak, 2006. Adsorption equilibria in the systems: Aqueous solutions of organics-oxidized activated carbon samples obtained from different parts of granules. Fuel, 85: 410-417.

Dotto, G.L., J.O. Goncalves, T.R.S. Cadaval and L.A.A. Pinto, 2013. Biosorption of phenol onto bionanoparticles from Spirulina sp. LEB 18. J. Coll. Inter. Sci., 407: 450-456.

EPA., 1995. Profile of the petroleum refining industry-EPA office of compliance sector notebook project. US EPA Achieve Documents, September 1995, pp: 1-190.

El-Naas, M.H., S. Al-Zuhair and M. Abu-AlHaija, 2010. Removal of phenol from petroleum refinery wastewater through adsorption on date-pit activated carbon. Chem. Engin. J., 162: 997-1005.

Farkas, V., A. Felinger, A. Hegedusova, I. Dekany and T. Pernyeszi, 2013. Comparative study of the kinetics and equilibrium of phenol biosorption on immobilized white-rot fungus Phanerochaete chrysosporium from aqueous solution. Coll. Surf. B: Biointerf., 103: 381-390.

Figuerola, E.L. and L. Erijman, 2010. Diversity of nitrifying bacteria in a full-scale petroleum refinery wastewater treatment plant experiencing unstable nitrification. J. Hazardous Mat., 181: 281-288.

Foo, K.Y. and B.H. Hameed, 2010. Insights into the modeling of adsorption isotherm systems. Chem. Eng. J., 156: 2-10.

Friman, H., A. Schechter, Y. Nitzan and R. Cahan, 2013. Phenol degradation in bio-electrochemical cells. Int. Biodeter. Biodegrad., 84: 155-160.

Hank, D., Z. Azi, S.A. Hocine, O. Chaalal and A. Hellal, 2014. Optimization of phenol adsorption onto bentonite by factorial design methodology. J. Ind. Eng. Chem., 20: 2256-2263.

Huang, J., X. Jin and S. Deng, 2012. Phenol adsorption on an N-methylacetamide-modified hypercrosslinked resin from aqueous solutions. Chem. Eng. J., 192: 192-200. 
Kalaiarasan, E. and T. Palvannan, 2014. Removal of phenols from acidic environment by horseradish peroxidase (HRP): Aqueous thermostabilization of HRP by polysaccharide additives. J. Taiwan Instit. Chem. Eng., 45: 625-634.

Karunarathne, H.D.S.S. and B.M.W.P.K. Amarasinghe, 2013. Fixed bed adsorption column studies for the removal of aqueous phenol from activated carbon prepared from sugarcane bagasse. Energy Procedia, 34: 83-90.

Knop, A. and L.A. Pilato, 1985. Phenolic Resins: Chemistry, Application and Performance-Future Directions. Springer-Verlag, Berlin, Heidelberg.

Kulkarni, S.J., R.W. Tapre, S.V. Patil and M.B. Sawarkar, 2013. Adsorption of phenol from wastewater in fluidized bed using coconut shell activated Carbon. Procedia Eng., 51: 300-307.

Kumar, P.S. and K. Kirthika, 2009. Equilibrium and kinetic study of adsorption of nickel from aqueous solution onto bael tree leaf powder. J. Eng. Sci. Technol., 4: 351-363.

Lamb, M., S. Adamowski, F. Jere and C.W. Kiesling,, 2010. Biological WWTP for coke battery wastewater discharge: Design, construction and start-up challenges and solutions. Iron Steel Technol., 7: 42-50.

Lavilla, I., S. Gil, M. Costas and C. Bendicho, 2012. Dispersive liquid-liquid microextraction combined with microvolume spectrophotometry to turn green the 5530 APHA standard method for determining phenols in water and wastewater. Talanta, 98: 197-202.

Lorenc-Grabowska, E., G. Gryglewicz and M.A. Diez, 2013. Kinetics and equilibrium study of phenol adsorption on nitrogen-enriched activated carbons. Fuel, 114: 235-243.

Mohanty, K., D. Das and M.N. Biswas, 2006. Preparation and characterization of activated carbons from Sterculia alata nutshell by chemical activation with zinc chloride to remove phenol from wastewater. Adsorption, 12: 119-132.

Monteiro, A.A., R.A. Boaventura and A.E. Rodrigues, 2000. Phenol biodegradation by Pseudomonas putida DSM 548 in a batch reactor. Biochem. Eng. J., 6: $45-49$

Moussavi, G. and R. Khosravi, 2011. The removal of cationic dyes from aqueous solutions by adsorption onto pistachio hull waste. Chem. Eng. Res. Des., 89: 2182-2189.

Nadavala, S.K., K. Swayampakula, V.M. Boddu and K. Abburi, 2009. Biosorption of phenol and o-chlorophenol from aqueous solutions on to chitosan-calcium alginate blended beads. J. Hazardous Mat., 162: 482-489.
Navarro, A.E., R.F. Portales, M.R. Sun-Kou and B.P. Llanos, 2008. Effect of $\mathrm{pH}$ on phenol biosorption by marine seaweeds. J. Hazardous Mat., 156: 405-411.

Ozdes, D., C. Duran and H.B. Senturk, 2011. Adsorptive removal of $\mathrm{Cd}$ (II) and $\mathrm{Pb}$ (II) ions from aqueous solutions by using Turkish illitic clay. J. Environ. Manage., 92: 3082-3090.

Pacurariu, C., G. Mihoc, A. Popa, S.G. Muntean and R. Ianos, 2013. Adsorption of phenol and p-chlorophenol from aqueous solutions on poly (styrene-co-divinylbenzene) functionalized materials. Chem. Eng. J., 222: 218-227.

Pai, S.L., Y.L. Hsu, N.M. Chong, C.S. Sheu and C.H. Chen, 1995. Continuous degradation of phenol by Rhodococcus sp. immobilized on granular activated carbon and in calcium alginate. Bioresour. Technol., 51: 37-42.

Palleroni, N.J., 1984. Gram-Negative Aerobic Rods and Cocci. In: Bergey's Manual of Determinative Bacteriology, Krieg, N.R. and J.G. Holt (Eds.). Williams and Wilkins, Baltimore, MD., pp: 140-406.

Pigatto, G., A. Lodi, E. Finocchio, M.S. Palma and A. Converti, 2013. Chitin as biosorbent for phenol removal from aqueous solution: Equilibrium, kinetic and thermodynamic studies. Chem. Eng. Proc. Proc. Intensif., 70: 131-139.

Piubeli, F., M.J. Grossman, F. Fantinatti-Garboggini and L.R. Durrant 2012. Enhanced reduction of COD and aromatics in petroleum-produced water using indigenous microorganisms and nutrient addition. Int. Biodeter. Biodegrad., 68: 78-84.

Praveen, P. and K.C. Loh, 2013. Simultaneous extraction and biodegradation of phenol in a hollow fiber supported liquid membrane bioreactor. J. Membrane Sci., 430: 242-251.

Qian, Q., Q. Chen, M. Machida, H. Tatsumoto, K. Mochidzuki and A. Sakoda, 2009. Removal of organic contaminants from aqueous solution by Cattle Manure Compost (CMC) derived activated carbons. Applied Surface Sci., 255: 6107-6114.

Qin, G., Y. Yao, W. Wei and T. Zhang, 2013. Preparation of hydrophobic granular silica aerogels and adsorption of phenol from water. Applied Surface Sci., 280: 806-811.

Rao, J.R. and T. Viraraghavan, 2002. Biosorption of phenol from an aqueous solution by Aspergillus niger biomass. Bioresour. Technol., 85: 165-171.

Sneath, P.H.A., 1986. Endospore Forming GRAM-Positive Rods and Cocci. In: Bergey's Manual of Determinative Bacteriology, Krieg, N.R. and J.G. Holt (Eds.). Williams and Wilkins, Baltimore, MD., pp: 1104-1207. 
Tu, W., Y.P. Lin and R. Bai, 2013. Removal of phenol in aqueous solutions by novel buoyant Composite photocatalysts and the kinetics. Separat. Purific. Technol., 115: 180-189.

Viero, A.F., T.M. de Melo, A.P.R. Torres, N.R. Ferreira, G.L. Sant'Anna Jr, C.P. Borges and V.M. Santiago, 2008. The effects of long-term feeding of high organic loading in a submerged membrane bioreactor treating oil refinery wastewater. J. Membrane Sci., 319: 223-230.

Wu, J. and H.Q. Yu, 2006. Biosorption of phenol and chlorophenols from aqueous solutions by fungal mycelia. Process Biochem., 41: 44-49.

Yan, L., H. Ma, B. Wang, W. Mao and Y. Chen, 2010. Advanced purification of petroleum refinery wastewater by catalytic vacuum distillation. J. Hazardous Mater., 178: 1120-1124.
Yan, L., H. Ma, B. Wang, Y. Wang and Y. Chen, 2011. Electrochemical treatment of petroleum refinery wastewater with three-dimensional Multi-phase electrode. Desalination, 276: 397-402.

Yavuz, Y., A.S. Koparal and U.B. Ogutveren, 2010. Treatment of petroleum refinery wastewater by electrochemical methods. Desalination, 258: 201-205.

Zain, N.N.M., N.A. Bakar, S. Mohamad and N.M. Saleh, 2014. Optimization of a greener method for removal phenol species by cloud point extraction and spectrophotometry. Spectrochim. Acta Part A: Mol. Biomol. Spectrosc., 118: 1121-1128.

Zidkova, L., J. Szokol, L. Rucka, M. Patek and J. Nesvera, 2013. Biodegradation of phenol using recombinant plasmid-carrying Rhodococcus erythropolis strains. Int. Biodeter. Biodegrad., 84: 179-184. 